\title{
Improvement of educational performance indicators in Peru through mathematical optimization
}

\author{
Lady Denisse Infante Acosta, Ing. ${ }^{1}$, Jonatán Edward Rojas Polo, Mg. ${ }^{1}$ \\ ${ }^{1}$ Pontificia Universidad Católica del Perú, Perú, lady.infantea@pucp.edu.pe, jrojasp@pucp.pe
}

\begin{abstract}
In recent years, the Peruvian Ministry of Education has been conducting census evaluations aimed at fourth-grade elementary and second-grade high school students, in the subjects of mathematics, reading comprehension, social sciences and science and technology, whose results are qualified as Before beginning, Beginning, In process or Satisfactory. According to the latest census (ECE 2018) applied to high school students, it is observed that, although the area of mathematics has the second highest percentage qualified as Satisfactory (14.1\%), it has the disadvantage of registering $36.4 \%$ as Beginning and $33.7 \%$ as Before beginning, which represents one of the biggest obstacles to achieve optimal academic performances across all subjects evaluated.
\end{abstract}

For these reasons, this research aims at improving and consolidating mathematical knowledge in high school students through the strategic distribution of tutoring centers, within the Lima Metropolitan Area. To achieve this, the ECE 2018 database was analyzed to cluster the results according to the districts constituting each of the five areas of Lima; subsequently, those areas in which centers are primarily required were identified; and finally, through mathematical optimization, the optimal number of centers required and their locations to maximize the coverage were determined.

Keywords-- Educational system, academic performance improvement, mathematical optimization, tutoring center

\section{INTRODUCTION}

In recent years, the educational level in Peru has improved in its performance indicators and achievements obtained by elementary and high school students, from both private and state schools. Since 2015, besides the sample evaluations, the Peruvian Ministry of Education (MINEDU), in collaboration with the Office of Quality Measurement of Learning (UMC, for its acronym in Spanish), has incorporated census evaluations aimed at students of fourth grade of elementary school and second grade of high school, considering the educational levels in Peru. This last group of students is qualified in four academic subjects: mathematics, reading comprehension, social sciences and science and technology.

The results are qualified using the following scale: Before beginning (the student has not achieved the necessary learning to be at the Beginning level), Beginning (the student has achieved very elementary learning regarding what was expected for his current grade), In process (the student has partially achieved the expected learning for his current grade; he is on the way to achieving it, but he still has difficulties) or Satisfactory (the student has achieved the expected learning for his current grade and he is prepared to face the learning challenges of the following grade).
The statistics of the last Student Census Evaluation (ECE, for its acronym in Spanish) [1], ECE 2018, show the percentage of students who are part of the group qualified as Satisfactory: $14.1 \%$ in mathematics $36.4 \%$ Beginning and $33.7 \%$ Before beginning), $16.2 \%$ in reading comprehension $(37.5 \%$ Beginning and $18.5 \%$ Before beginning), $11.6 \%$ in social sciences (29.8\% Beginning and 22.4\% Before beginning), $8.5 \%$ in science and technology (43.1\% Beginning and $10.4 \%$ Before beginning). It is concluded that, although the subject of mathematics has the second highest percentage qualified as Satisfactory, it is also the one with the highest cumulative percentage $(70.1 \%)$, considering the two lowest qualifiers (Before beginning and Beginning).

Based on these results, it is observed that one of the most important variables to improve is the average qualification obtained in the subject of mathematics, for which this investigation seeks to propose a strategic distribution of tutoring centers for high school students, delimited within the Lima Metropolitan Area. For the evaluation of the project, the ECE 2018 database will be analyzed in order to cluster the results of the evaluation considering the geographical area mentioned; following this, the filtered results will be grouped by each district area of the Lima Metropolitan Area (Norte, Este, Sur, Centro y Moderna); subsequently, those areas where the tutoring centers are required as a priority will be evaluated and determined; and, finally, through a mathematical optimization model, the required number of centers will be found and thus the locations of each of these will be established.

\section{STATE OF THE ART}

Tutoring centers, which are focused on improving the educational level, are an aspect that is transversely present in different countries around the world, regardless of the geographical location or the development level of the country. The utility given varies depending on the objectives of each student; this alternative education can support the understanding or reinforcement of different issues, as well as strengthen the performance in those that are already mastered. The demand for this kind of service is mainly required by high school students, compared to elementary ones [2].

Among the factors associated with the performance obtained by students, the parental educational attainment and the household income (represented by the GDP) are perceived as the main ones; in other words, the assumption that a better index in these variables generates a better academic achievement is proposed. Based on a comparison between these 
variables and the results obtained in the PISA evaluation, specifically with the MARA index (Mathematics and Reading Ability), the existing relationships are identified. On the one hand, there is a positive correlation between household income and MARA results as for the poorest countries; however, the impact of this factor declines as the wealthier ones are analyzed. On the other hand, parental educational attainment has a positive impact on the educational performance of children as for the wealthiest countries; however, this relationship decreases as the poorer ones are analyzed [3].

In Latin America, the average result obtained in the PISA assessments is lower than the average obtained in other countries in which educational standards are similar; thus, the latent inequality in the socioeconomic conditions within most countries of this region plays an important role in the results of this evaluation [4]. In the case of Peru, it is observed that family wealth is more relevant compared to the parental educational attainment in terms of its relation to the academic performance demonstrated through the MARA score [3]. In this context, it can be inferred that greater purchasing power could lead to a higher level and better quality of education, given that there is not necessarily democratization of resources in the country concerned. In consequence, an alternative present in various countries where there is such inequality of conditions is the use of private tutoring to reinforce or improve student learning.

The main advantage of private tutoring is that it is developed according to the student needs: once his strengths and weaknesses have been identified, a methodology focused on improving the shortcomings and consolidating the knowledge already acquired is proposed [5]. However, the counterpart of this tutoring must be kept in mind, since sometimes the resolution of exercises can become mechanical, especially in the case of topics associated with mathematics, and the objective of these private classes must be to improve the understanding of theoretical principles [2].

\section{ANALYSIS OF THE ECE 2018 RESUlTS}

The Student Census Evaluation measures what and how many students are learning from public and private schools [6]. The databases provided by the Peruvian Ministry of Education include the results of fourth grade of elementary school and second grade of high school. In the case of the last one, there are a total of 535,146 records including the assessments applied to the twenty-five regions of Peru; specifically, in the case of the Lima Metropolitan Area, there are a total of 140,371 observations for a total of forty-two censored districts. Table I shows the detail and consolidation of the total surveys conducted by district and grouped by each area of Lima. There are cases with missing values and, in order to complete that information, the database provides adjustment factors. Table II explains the algorithm to calculate the percentages of students for each level of achievement [7].
TABLE I

TOTAL OF SURVEYS CONDUCTED BY DISTRICT AND GROUPED BY EACH AREA OF THE LiMA METROPOLITAN AREA - ECE 2018

\begin{tabular}{|c|c|c|c|}
\hline District area & District & $\begin{array}{l}\text { Total per } \\
\text { district }\end{array}$ & $\begin{array}{c}\text { Total per } \\
\text { district area }\end{array}$ \\
\hline \multirow{8}{*}{ Lima Norte } & Ancón & 1,002 & \multirow{8}{*}{40,327} \\
\hline & Carabayllo & 5,108 & \\
\hline & Comas & 9,101 & \\
\hline & Independencia & 2,637 & \\
\hline & Los Olivos & 7,087 & \\
\hline & Puente Piedra & 5,826 & \\
\hline & San Martin de Porres & 9,377 & \\
\hline & Santa Rosa & 189 & \\
\hline \multirow{7}{*}{ Lima Este } & Ate & 10,090 & \multirow{7}{*}{37,107} \\
\hline & Chaclacayo & 1,022 & \\
\hline & Cieneguilla & 373 & \\
\hline & El Agustino & 2,178 & \\
\hline & Lurigancho & 3,538 & \\
\hline & San Juan de Lurigancho & 16,218 & \\
\hline & Santa Anita & 3,688 & \\
\hline \multirow{5}{*}{ Lima Centro } & Breña & 2,023 & \multirow{5}{*}{13,161} \\
\hline & La Victoria & 2,200 & \\
\hline & Lima & 5,093 & \\
\hline & Rímac & 2,807 & \\
\hline & San Luis & 1,038 & \\
\hline \multirow{10}{*}{ Lima Sur } & Chorrillos & 5,497 & \multirow{10}{*}{29,726} \\
\hline & Lurín & 1,511 & \\
\hline & Pachacamac & 1,971 & \\
\hline & Pucusana & 216 & \\
\hline & Punta Hermosa & 72 & \\
\hline & Punta negra & 129 & \\
\hline & San Bartolo & 151 & \\
\hline & San Juan de Miraflores & 6,305 & \\
\hline & Villa El Salvador & 6,616 & \\
\hline & Villa María del Triunfo & 7,258 & \\
\hline \multirow{12}{*}{ Lima Moderna } & Barranco & 1,441 & \multirow{12}{*}{20,050} \\
\hline & Jesús María & 1,420 & \\
\hline & La Molina & 2,991 & \\
\hline & Lince & 862 & \\
\hline & Magdalena del Mar & 819 & \\
\hline & Miraflores & 1,772 & \\
\hline & Pueblo Libre & 997 & \\
\hline & San Borja & 1,142 & \\
\hline & San Isidro & 1,117 & \\
\hline & San Miguel & 2,499 & \\
\hline & Santiago de Surco & 4,040 & \\
\hline & Surquillo & 950 & \\
\hline
\end{tabular}

Source: MINEDU - UMC. Evaluación Censal de Estudiantes 2018. Segundo grado de secundaria

Table III presents the results disaggregated by levels of achievement in mathematics and crossed by four variables: sex, management, geographical area and district area of the Lima Metropolitan Area. Finally, in Table IV, the results obtained by each district are examined according to each level of achievement in order to identify which are the most critics in the two lowest levels (Before beginning and Beginning) and then estimate the number of students that will be part of the target group of the tutoring centers. 
TABLE II

ALGORITHM TO CALCULATE THE PERCENTAGE OF STUDENTS FOR EACH LEVEL OF ACHIEVEMENT

\begin{tabular}{|c|c|c|}
\hline Step & Description & Operation \\
\hline 1 & Classification of the results & $\begin{array}{l}\text { The following scale is used to classify the scores obtained in the subject of mathematics. } \\
\qquad \text { Classification }= \begin{cases}\text { Before beginning, } & \text { M500_M }<520 \\
\text { Beginning, } & 520 \leq \text { M500_M }<596 \\
\text { In process, } & 596 \leq \text { M500_M }<649 \\
\text { Satisfactory, } & 649 \leq \text { M500_M }\end{cases} \\
\text { Where M500_M is the score obtained in the evaluation }\end{array}$ \\
\hline 2 & $\begin{array}{l}\text { Assignment of the non-response adjustment } \\
\text { factor }\end{array}$ & 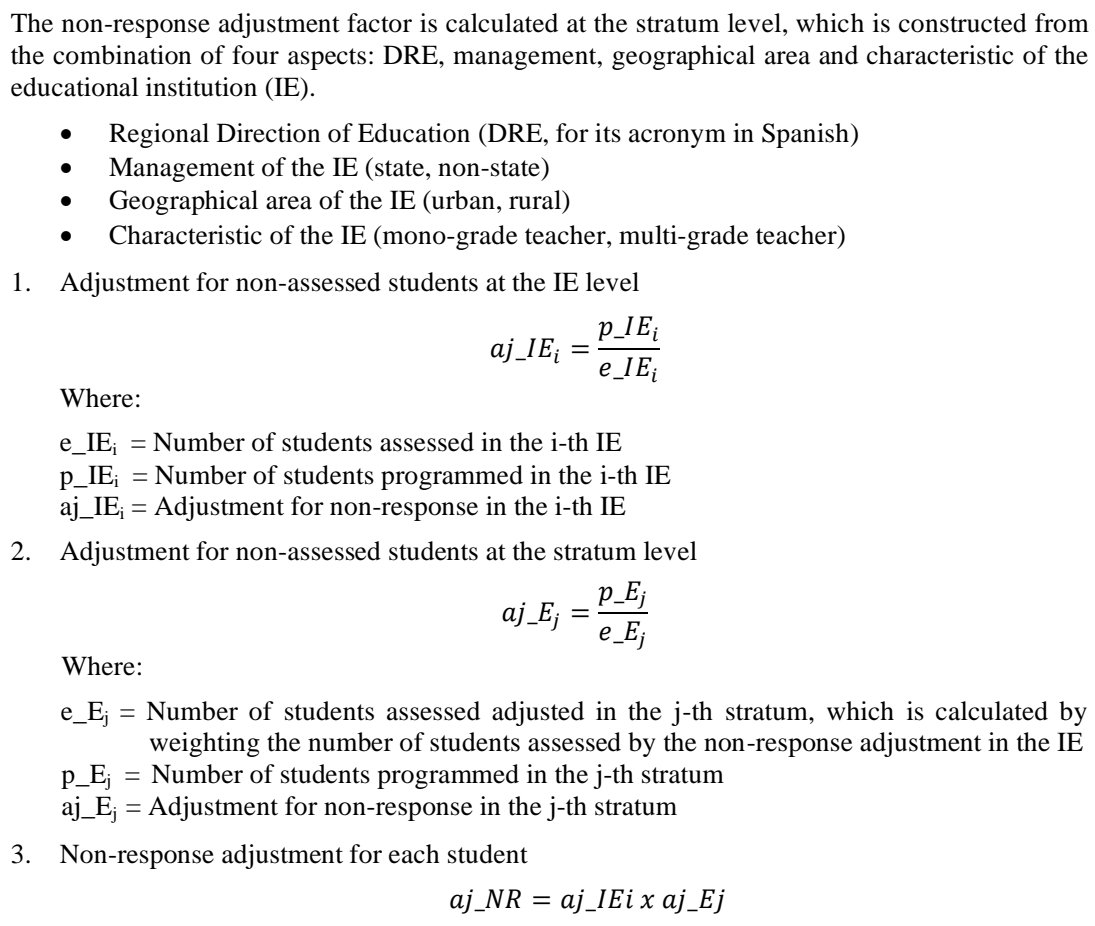 \\
\hline 3 & $\begin{array}{l}\text { Application of the non-response adjustment } \\
\text { factor }\end{array}$ & $\begin{array}{l}\text { To obtain the percentage of students at each level of achievement ('Before beginning', } \\
\text { 'Beginning', 'In process' and 'Satisfactory'), it is necessary to multiply the data of each student } \\
\text { by the non-response adjustment factor. In the database, aj_m represents the factor for the subject } \\
\text { of mathematics. } \\
\text { Because 'grupo_M' is a nominal attribute, a value will be assigned to transform it into a number. } \\
\qquad \text { grupo_M } M= \begin{cases}1, & \text { if grupo_M: } \text { Before beginning } \\
2, & \text { if grupo_M: } \text { Beginning } \\
3, & \text { if grupo_M:In process } \\
4, & \text { if grupo_M:Satisfactory }\end{cases} \end{array}$ \\
\hline 4 & $\begin{array}{l}\text { Calculation of the total number of students for } \\
\text { each level of achievement }\end{array}$ & $\begin{array}{l}\text { This formula is used to calculate the total number of students for each level of achievement. } \\
\text { For } \mathrm{k}=1 \text { to } \mathrm{k}=4 \text { : } \\
\qquad \text { Total_grupo_M } M_{k}=\frac{\sum_{i_{k}}^{n_{k}} \text { grupo_M_ponderado }}{k} \\
\text { Where: } \\
\mathrm{i}_{\mathrm{k}}: \text { First register, where grupo_M }=\mathrm{k} \\
\mathrm{n}_{\mathrm{k}}: \text { Last register, where grupo_M }=\mathrm{k}\end{array}$ \\
\hline 5 & $\begin{array}{l}\text { Calculation of the percentage of students for } \\
\text { each level of achievement }\end{array}$ & $\begin{array}{l}\text { This formula is used to calculate the percentage of students for each level of achievement. } \\
\text { For } \mathrm{k}=1 \text { to } \mathrm{k}=4 \text { : } \\
\qquad \text { Porc_grupo_ } M_{k}=\frac{\text { Total_grupo_ } M_{k}}{\sum_{i=1}^{4} \text { Total_grupo_M } M_{i}}\end{array}$ \\
\hline
\end{tabular}

Source: MINEDU - UMC. Reporte técnico de las Evaluaciones Censales y Muestrales de Estudiantes 2018

$18^{\text {th }}$ LACCEI International Multi-Conference for Engineering, Education, and Technology: "Engineering, Integration, and Alliances for a Sustainable Development" "Hemispheric Cooperation for Competitiveness and Prosperity on a Knowledge-Based Economy", 29-31 July 2020, Buenos Aires, Argentina. 
TABLE III

RESULTS BY LEVELS OF ACHIEVEMENT IN MATHEMATICS ACCORDING TO SEX, MANAGEMENT, GEOGRAPHICAL AREA AND DISTRICT AREA

\begin{tabular}{|c|c|c|c|c|c|c|c|c|c|c|c|c|}
\hline \multirow{2}{*}{$\begin{array}{c}\text { Level of } \\
\text { achievement }\end{array}$} & \multirow[b]{2}{*}{ Total } & \multicolumn{2}{|c|}{ Sex } & \multicolumn{2}{|c|}{ Management } & \multicolumn{2}{|c|}{ Geographical area } & \multicolumn{5}{|c|}{ District area of the Lima Metropolitan Area } \\
\hline & & Male & Female & State & Non-state & Urban & Rural & $\begin{array}{l}\text { Lima } \\
\text { Norte }\end{array}$ & $\begin{array}{l}\text { Lima } \\
\text { Este }\end{array}$ & $\begin{array}{c}\text { Lima } \\
\text { Centro }\end{array}$ & $\begin{array}{l}\text { Lima } \\
\text { Sur }\end{array}$ & $\begin{array}{c}\text { Lima } \\
\text { Moderna }\end{array}$ \\
\hline Before beginning & $20.6 \%$ & $18.7 \%$ & $22.6 \%$ & $25.1 \%$ & $15.4 \%$ & $20.6 \%$ & $27.6 \%$ & $22.4 \%$ & $21.0 \%$ & $20.2 \%$ & $23.8 \%$ & $11.9 \%$ \\
\hline Beginning & $38.4 \%$ & $37.2 \%$ & $39.6 \%$ & $40.8 \%$ & $35.7 \%$ & $38.4 \%$ & $38.1 \%$ & $40.3 \%$ & $39.5 \%$ & $38.1 \%$ & $40.2 \%$ & $30.1 \%$ \\
\hline In process & $20.7 \%$ & $21.3 \%$ & $20.1 \%$ & $18.7 \%$ & $23.0 \%$ & $20.7 \%$ & $17.5 \%$ & $20.0 \%$ & $20.8 \%$ & $21.5 \%$ & $19.1 \%$ & $24.0 \%$ \\
\hline Satisfactory & $20.2 \%$ & $22.8 \%$ & $17.6 \%$ & $15.4 \%$ & $25.8 \%$ & $20.2 \%$ & $16.8 \%$ & $17.3 \%$ & $18.7 \%$ & $20.2 \%$ & $16.9 \%$ & $34.0 \%$ \\
\hline
\end{tabular}

Source: MINEDU - UMC. Evaluación Censal de Estudiantes 2018. Segundo grado de secundaria

TABLE IV

TOTAL NUMBER OF STUDENTS PER DISTRICT BELONGING TO THE TARGET GROUP

\begin{tabular}{|c|c|c|c|c|c|c|c|c|}
\hline \multirow[b]{2}{*}{ District area } & \multirow[b]{2}{*}{ District } & \multicolumn{4}{|c|}{ Level of achievement } & \multirow{2}{*}{$\begin{array}{c}\text { Priority } \\
\begin{array}{c}\text { Before beginning } \\
+ \text { Beginning }\end{array}\end{array}$} & \multirow{2}{*}{$\begin{array}{l}\text { Population } \\
\text { from } 11 \text { to } \\
17 \text { years old } \\
\end{array}$} & \multirow{2}{*}{$\begin{array}{l}\text { Target } \\
\text { group }\end{array}$} \\
\hline & & $\begin{array}{c}\text { Before } \\
\text { beginning }\end{array}$ & Beginning & In process & Satisfactory & & & \\
\hline \multirow{8}{*}{ Lima Norte } & Ancón & $24.8 \%$ & $40.5 \%$ & $21.2 \%$ & $13.5 \%$ & $65.3 \%$ & 6,471 & 4,224 \\
\hline & \begin{tabular}{|l|} 
Carabayllo \\
\end{tabular} & $26.7 \%$ & $41.3 \%$ & $18.2 \%$ & $13.7 \%$ & $68.1 \%$ & 39,986 & 27,220 \\
\hline & \begin{tabular}{|l|} 
Comas \\
\end{tabular} & $24.0 \%$ & $40.0 \%$ & $19.3 \%$ & $16.6 \%$ & $64.0 \%$ & 55,699 & 35,651 \\
\hline & \begin{tabular}{|l} 
Independencia \\
\end{tabular} & $28.0 \%$ & $42.2 \%$ & $17.8 \%$ & $12.0 \%$ & $70.2 \%$ & 22,615 & 15,873 \\
\hline & Los Olivos & $16.8 \%$ & $37.9 \%$ & $21.7 \%$ & $23.7 \%$ & $54.7 \%$ & 31,512 & 17,231 \\
\hline & \begin{tabular}{|l|} 
Puente Piedra \\
\end{tabular} & $23.6 \%$ & $40.1 \%$ & $20.9 \%$ & $15.3 \%$ & $63.8 \%$ & 38,799 & 24,748 \\
\hline & \begin{tabular}{|l|} 
San Martín de Porres \\
\end{tabular} & $20.2 \%$ & $41.2 \%$ & $20.4 \%$ & $18.2 \%$ & $61.5 \%$ & 67,361 & 41,398 \\
\hline & \begin{tabular}{|l|} 
Santa Rosa \\
\end{tabular} & $24.4 \%$ & $47.7 \%$ & $16.3 \%$ & $11.6 \%$ & $72.1 \%$ & 3,140 & 2,265 \\
\hline \multirow{7}{*}{ Lima Este } & Ate & $18.6 \%$ & $39.5 \%$ & $21.6 \%$ & $20.2 \%$ & $58.2 \%$ & 67,433 & 39,223 \\
\hline & Chaclacayo & $17.5 \%$ & $34.6 \%$ & $22.2 \%$ & $25.7 \%$ & $52.1 \%$ & 4,478 & 2,333 \\
\hline & \begin{tabular}{|l|} 
Cieneguilla \\
\end{tabular} & $22.3 \%$ & $43.7 \%$ & $18.6 \%$ & $15.4 \%$ & $66.0 \%$ & 4,048 & 2,672 \\
\hline & El Agustino & $25.4 \%$ & $39.5 \%$ & $19.1 \%$ & $16.0 \%$ & $64.9 \%$ & 21,350 & 13,851 \\
\hline & Lurigancho & $20.9 \%$ & $38.8 \%$ & $20.7 \%$ & $19.7 \%$ & $59.6 \%$ & 28,317 & 16,891 \\
\hline & \begin{tabular}{|l|} 
San Juan de Lurigancho \\
\end{tabular} & $22.6 \%$ & $40.3 \%$ & $20.2 \%$ & $16.9 \%$ & $62.9 \%$ & 111,701 & 70,297 \\
\hline & Santa Anita & $18.7 \%$ & $37.7 \%$ & $21.9 \%$ & $21.8 \%$ & $56.3 \%$ & 19,993 & 11,262 \\
\hline \multirow{5}{*}{ Lima Centro } & Breña & $13.5 \%$ & $34.2 \%$ & $23.5 \%$ & $28.8 \%$ & $47.7 \%$ & 7,779 & 3,710 \\
\hline & \begin{tabular}{|l|} 
La Victoria \\
\end{tabular} & $25.3 \%$ & $39.9 \%$ & $19.4 \%$ & $15.4 \%$ & $65.2 \%$ & 16,473 & 10,745 \\
\hline & \begin{tabular}{|l|} 
Lima \\
\end{tabular} & $19.9 \%$ & $37.6 \%$ & $22.0 \%$ & $20.5 \%$ & $57.5 \%$ & 24,789 & 14,254 \\
\hline & Rímac & $23.8 \%$ & $40.5 \%$ & $19.5 \%$ & $16.1 \%$ & $64.4 \%$ & 17,476 & 11,250 \\
\hline & \begin{tabular}{|l|} 
San Luis \\
\end{tabular} & $14.1 \%$ & $38.0 \%$ & $25.2 \%$ & $22.7 \%$ & $52.1 \%$ & 4,647 & 2,422 \\
\hline \multirow{10}{*}{ Lima Sur } & \begin{tabular}{|l|} 
Chorrillos \\
\end{tabular} & $16.4 \%$ & $36.7 \%$ & $21.3 \%$ & $25.6 \%$ & $53.1 \%$ & 33,159 & 17,596 \\
\hline & \begin{tabular}{|l|} 
Lurín \\
\end{tabular} & $21.0 \%$ & $39.7 \%$ & $20.9 \%$ & $18.3 \%$ & $60.7 \%$ & 10,488 & 6,368 \\
\hline & Pachacamac & $23.9 \%$ & $40.0 \%$ & $19.9 \%$ & $16.3 \%$ & $63.9 \%$ & 13,626 & 8,705 \\
\hline & \begin{tabular}{|l|} 
Pucusana \\
\end{tabular} & $33.8 \%$ & $38.7 \%$ & $16.8 \%$ & $10.8 \%$ & $72.5 \%$ & 1,843 & 1,336 \\
\hline & \begin{tabular}{|l|} 
Punta Hermosa \\
\end{tabular} & $31.9 \%$ & $43.1 \%$ & $13.9 \%$ & $11.1 \%$ & $75.0 \%$ & 1,549 & 1,162 \\
\hline & \begin{tabular}{|l|} 
Punta Negra \\
\end{tabular} & $28.6 \%$ & $38.1 \%$ & $23.3 \%$ & $10.1 \%$ & $66.6 \%$ & 768 & 512 \\
\hline & San Bartolo & $26.2 \%$ & $43.6 \%$ & $15.4 \%$ & $14.8 \%$ & $69.8 \%$ & 730 & 510 \\
\hline & San Juan de Miraflores & $23.8 \%$ & $40.2 \%$ & $19.4 \%$ & $16.6 \%$ & $64.0 \%$ & 36,647 & 23,460 \\
\hline & \begin{tabular}{|l|} 
Villa El Salvador \\
\end{tabular} & $27.1 \%$ & $41.0 \%$ & $17.7 \%$ & $14.3 \%$ & $68.1 \%$ & 44,894 & 30,562 \\
\hline & \begin{tabular}{|l|} 
Villa María del Triunfo \\
\end{tabular} & $26.5 \%$ & $42.2 \%$ & $18.1 \%$ & $13.2 \%$ & $68.7 \%$ & 45,241 & 31,074 \\
\hline \multirow{12}{*}{ Lima Moderna } & \begin{tabular}{|l|} 
Barranco \\
\end{tabular} & $14.2 \%$ & $34.9 \%$ & $24.4 \%$ & $26.5 \%$ & $49.1 \%$ & 2,673 & 1,312 \\
\hline & \begin{tabular}{|l|} 
Jesús María \\
\end{tabular} & $12.7 \%$ & $32.6 \%$ & $24.5 \%$ & $30.1 \%$ & $45.3 \%$ & 5,549 & 2,516 \\
\hline & \begin{tabular}{|l|} 
La Molina \\
\end{tabular} & $8.4 \%$ & $27.4 \%$ & $25.2 \%$ & $39.0 \%$ & $35.8 \%$ & 13,282 & 4,753 \\
\hline & \begin{tabular}{|l|} 
Lince \\
\end{tabular} & $15.6 \%$ & $32.0 \%$ & $21.3 \%$ & $31.1 \%$ & $47.6 \%$ & 4,018 & 1,913 \\
\hline & \begin{tabular}{|l|} 
Magdalena del Mar \\
\end{tabular} & $18.9 \%$ & $34.4 \%$ & $22.9 \%$ & $23.7 \%$ & $53.3 \%$ & 4,734 & 2,526 \\
\hline & \begin{tabular}{|l|} 
Miraflores \\
\end{tabular} & $10.6 \%$ & $28.0 \%$ & $24.1 \%$ & $37.3 \%$ & $38.6 \%$ & 5,794 & 2,238 \\
\hline & \begin{tabular}{|l|} 
Pueblo Libre \\
\end{tabular} & $9.7 \%$ & $30.3 \%$ & $26.2 \%$ & $33.9 \%$ & $39.9 \%$ & 6,624 & 2,646 \\
\hline & \begin{tabular}{|l|} 
San Borja \\
\end{tabular} & $11.3 \%$ & $30.7 \%$ & $24.5 \%$ & $33.5 \%$ & $42.0 \%$ & 8,326 & 3,500 \\
\hline & \begin{tabular}{|l|} 
San Isidro \\
\end{tabular} & $5.5 \%$ & $23.8 \%$ & $27.9 \%$ & $42.8 \%$ & $29.3 \%$ & 4,186 & 1,225 \\
\hline & \begin{tabular}{|l|} 
San Miguel \\
\end{tabular} & $14.3 \%$ & $33.9 \%$ & $23.8 \%$ & $28.1 \%$ & $48.2 \%$ & 13,778 & 6,636 \\
\hline & \begin{tabular}{|l|} 
Santiago de Surco \\
\end{tabular} & $10.9 \%$ & $27.5 \%$ & $22.6 \%$ & $39.0 \%$ & $38.4 \%$ & 29,445 & 11,308 \\
\hline & Surquillo & $18.9 \%$ & $33.7 \%$ & $22.2 \%$ & $25.1 \%$ & $52.7 \%$ & 7,288 & 3,841 \\
\hline
\end{tabular}

Source: MINEDU - UMC. Evaluación Censal de Estudiantes 2018. Segundo grado de secundaria, INEI - Resultados definitivos de los censos nacional 2017 Provincia de Lima, tomo I

$18^{\text {th }}$ LACCEI International Multi-Conference for Engineering, Education, and Technology: "Engineering, Integration, and Alliances for a Sustainable Development" "Hemispheric Cooperation for Competitiveness and Prosperity on a Knowledge-Based Economy", 29-31 July 2020, Buenos Aires, Argentina. 
From these results, it is noted that the lowest scores are registered in state schools. Likewise, analyzing by district areas, Lima Moderna, which has the best socioeconomic conditions, is the only one having a remarkable percentage of students with good scores (58\%, In process and Satisfactory); however, this does not happen in the other areas. In Lima Norte, Lima Este, Lima Centro and Lima Sur, approximately six of every ten students have difficulties to achieve the level of learning expected for their current grade. The lowest scores in both Before beginning and Beginning levels of achievement are registered in districts such as Punta Hermosa, Independencia, Villa María del Triunfo and Villa El Salvador; nevertheless, it is so important to transform the percentages obtained in these two categories into quantities to obtain the number of students that will be part of the target group of the tutoring centers.

To obtain the number of students, data from the census conducted in 2017 by the National Institute of Statistics and Informatics of Peru (INEI, for its acronym in Spanish) has been used [8]. The data is presented disaggregated by each year of age. High school students are between twelve and sixteen years old on average, but a margin of one year is added to the limit values to get flexibility in the range of age, which, in consequence, considers the total number of people who are between eleven and seventeen years old. It should be mentioned that there is the assumption that all people within the indicated age range attend high school.

\section{PROPOSED METHODOLOGY}

For determining the total number of tutoring centers and their respective locations, it has been proposed to analyze each district area of the Lima Metropolitan Area as separate modules and, within each district area, the districts composing it have been divided into zones (subdivisions) in order to be able to analyze it at a more detailed geographical level. It is necessary to mention that the zones have been divided considering the main avenues as references and the total of inhabitants per zone is determined using the ratio of the total number of persons belonging to the target group per square kilometer. Then, once the zones of each district have been identified and graphically represented, the map of the analyzed district area is divided into quadrants to establish the possible locations of the tutoring centers. To solve the problem raised, an optimization model using linear programming has been proposed. The variables defined for the algorithm are the following:

- $\mathrm{P}_{\mathrm{k}}$ : It represents the number of students per each zone of the districts that potentially will require the service.

- $\mathrm{X}_{\mathrm{i}}$ : It represents each possible quadrant where the center could be located.

- $\mathrm{C}_{\mathrm{j}}$ : It represents alternatives for the maximum number of students that may attend each tutoring center.

- $\mathrm{X}_{\mathrm{i}} \mathrm{C}_{\mathrm{j}}$ : It represents each possible combination of capacity per quadrant where the center could be located.
Subject to:

$$
\text { minimize } \sum_{i=1}^{n} X_{i}
$$

$$
\begin{array}{ll}
\sum_{i \in I_{k}} X_{i} \geq 1 & ; \quad \forall \mathrm{k}=1, \ldots, \mathrm{t} \\
\sum_{i \in I_{k}} \sum_{j \in J_{k}} X_{i} C_{j} * C_{j} \geq P_{k} & ; \quad \forall \mathrm{k}=1, \ldots, \mathrm{t} \\
\sum_{j \in J_{k}} X_{i} C_{j}=X_{i} & \forall \mathrm{i}=1, \ldots, \mathrm{n}
\end{array}
$$

Non-negativity constraints:

$$
X_{i}, X_{i} C_{j} \in\{0,1\}
$$

The number of tutoring centers required is minimized in (1). It is guaranteed in (2) that there is at least one tutoring center covering the demand of the subdivision $\mathrm{k}$. It is ensured in (3) that the accumulated capacity of the total number of tutoring centers around zone $\mathrm{k}$ can cover at least the demand of that sector. The algorithm is restricted in (4) to select only one alternative of capacity for each selected tutoring center. Finally, the variables to be determined are defined as binary in (5).

In order to give an example of the methodology, the district area of Lima Centro has been analyzed. Table V presents the potential demand of students who will possibly use the service, detailed for each district. In addition, Fig. 1 adapts the map of Lima Centro with some attributes to apply the methodology; as

\begin{tabular}{|c|c|c|}
\hline District & $\begin{array}{c}\text { Zone } \\
\text { (subdivision) }\end{array}$ & $\begin{array}{c}\text { Target } \\
\text { Demand }\end{array}$ \\
\hline \multirow{7}{*}{ Rímac } & $\mathrm{P} 1$ & 1,637 \\
\hline & $\mathrm{P} 2$ & 1,475 \\
\hline & P3 & 1,486 \\
\hline & $\mathrm{P} 4$ & 743 \\
\hline & P5 & 1,498 \\
\hline & P6 & 1,567 \\
\hline & P7 & 2,844 \\
\hline \multirow{9}{*}{ Lima } & P8 & 1,877 \\
\hline & P9 & 1,068 \\
\hline & $\mathrm{P} 10$ & 1,095 \\
\hline & P11 & 1,395 \\
\hline & P12 & 1,570 \\
\hline & $\mathrm{P} 13$ & 935 \\
\hline & P14 & 1,758 \\
\hline & P15 & 2,944 \\
\hline & P16 & 1,612 \\
\hline \multirow{3}{*}{ Breña } & P17 & 1,491 \\
\hline & P18 & 967 \\
\hline & P19 & 1,252 \\
\hline
\end{tabular}
a result, the districts, their zones and the quadrants delimiting

\begin{tabular}{|c|c|c|}
\hline District & $\begin{array}{c}\text { Zone } \\
\text { (subdivision) }\end{array}$ & $\begin{array}{c}\text { Target } \\
\text { Demand }\end{array}$ \\
\hline \multirow{12}{*}{$\begin{array}{c}\text { La } \\
\text { Victoria }\end{array}$} & P20 & 1,049 \\
\hline & P21 & 594 \\
\hline & P22 & 1,142 \\
\hline & $\mathrm{P} 23$ & 851 \\
\hline & P24 & 1,166 \\
\hline & $\mathrm{P} 25$ & 629 \\
\hline & P26 & 559 \\
\hline & $\mathrm{P} 27$ & 688 \\
\hline & P28 & 1,002 \\
\hline & P29 & 804 \\
\hline & P30 & 1,096 \\
\hline & P31 & 1,165 \\
\hline \multirow{6}{*}{$\begin{array}{l}\text { San } \\
\text { Luis }\end{array}$} & P32 & 206 \\
\hline & P33 & 463 \\
\hline & P34 & 528 \\
\hline & P35 & 527 \\
\hline & $\mathrm{P} 36$ & 228 \\
\hline & P37 & 470 \\
\hline
\end{tabular}
the possible locations of the tutoring centers are shown.

TABLE V

POTENTIAL DEMAND OF STUDENTS PER DISTRICT SUBDIVISION 


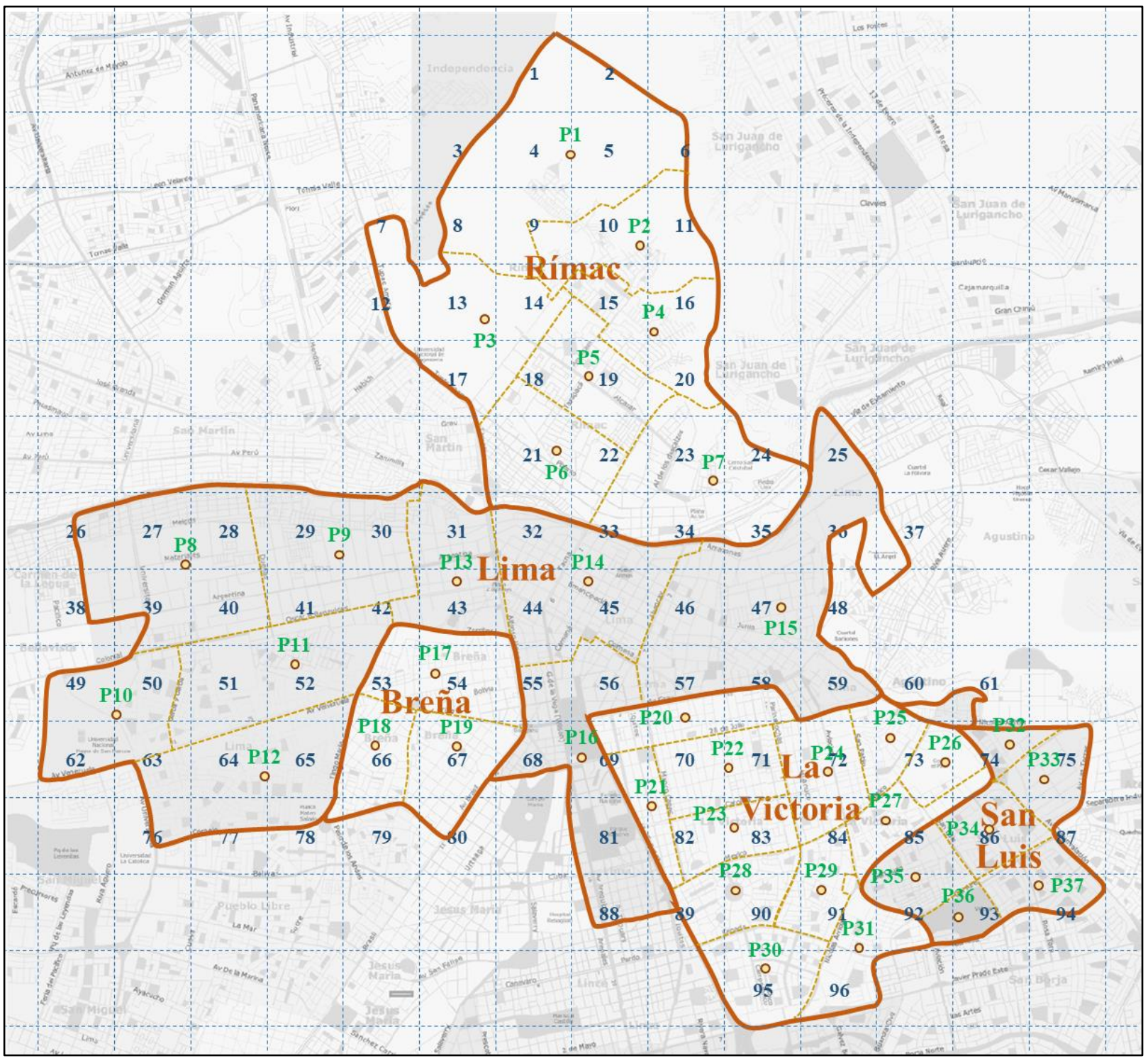

Fig. 1 Graphics settings of the map of Lima Centro to apply the methodology (districts, zones of districts and quadrants) Source: www.guiacalles.com - Guía de calles del Perú (Image) 
For each zone, the quadrants that are part of it or limit with its edges are analyzed. For example, there are seven zones in the case of the district of Rímac; particularly, the demand of the subdivision $\mathrm{P} 1$ has to be evaluated considering the quadrants 1 , $2,3,4,5,6,8,9,10,11,13$ and 14 .

\section{Codification}

The coding will be done based on the software available to the organization under study, the LINGO software (CPLEX will not be used).

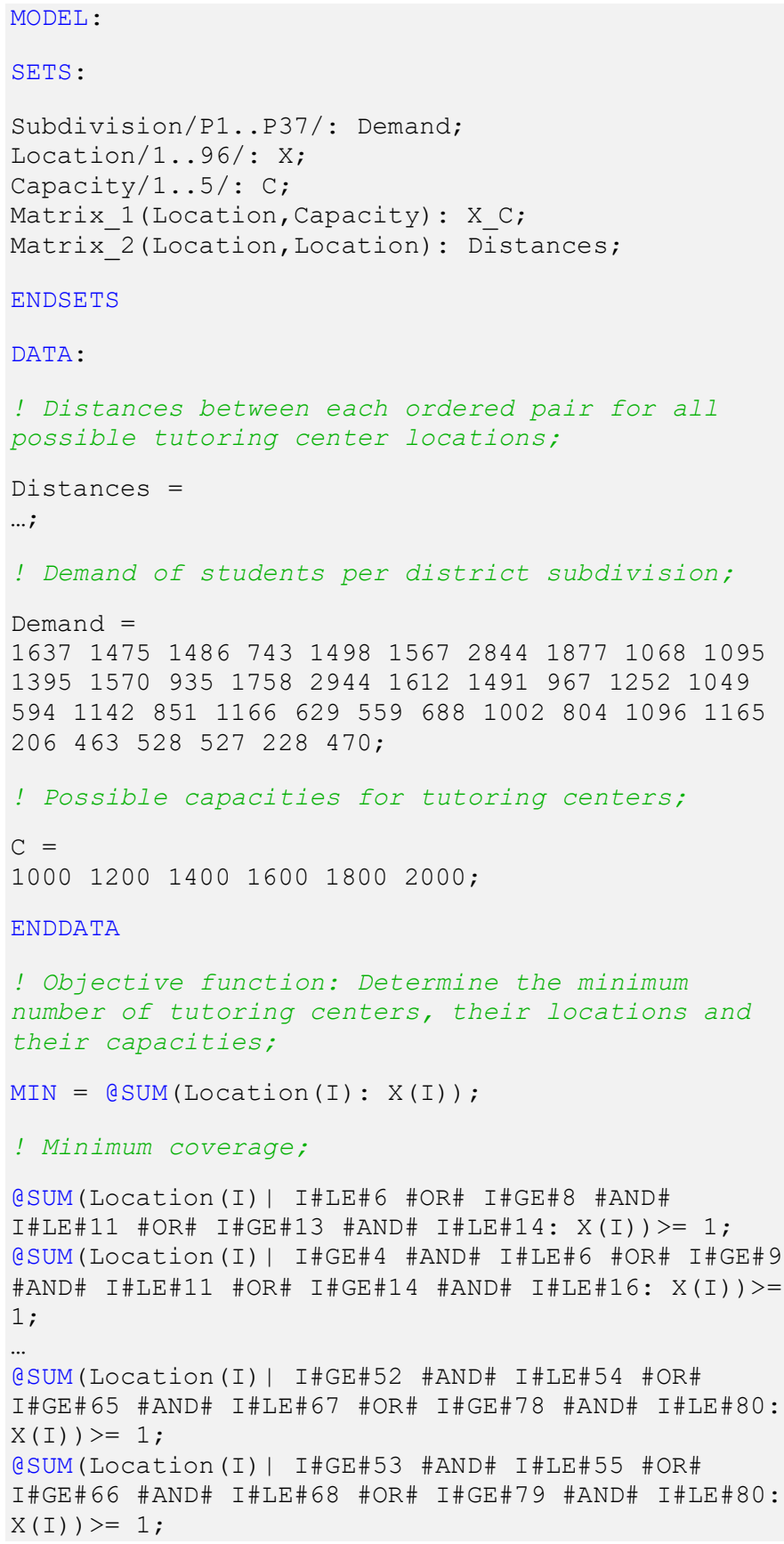

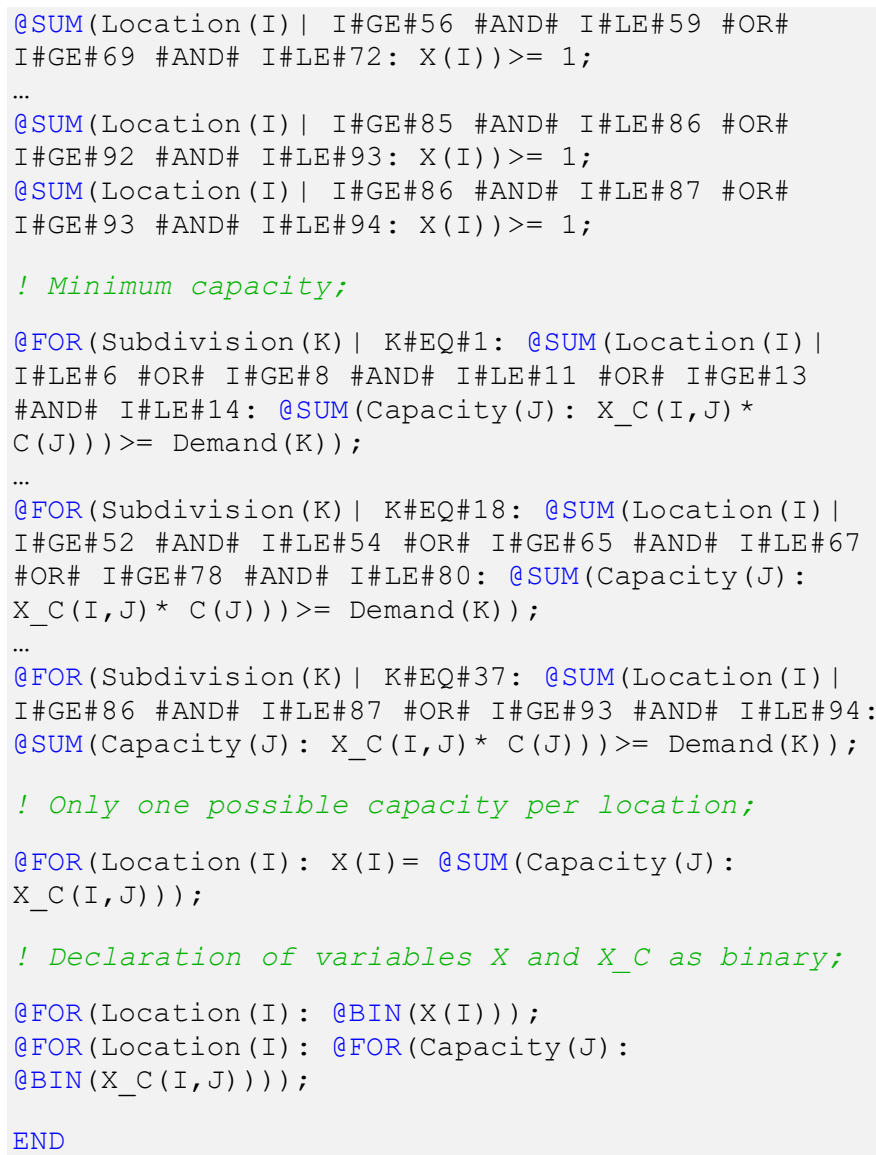

\section{RESULTS}

Considering the mentioned criteria, the algorithm has been programmed in the software Lingo, which allows formulating problems of linear and non-linear programming. As a result, it is determined that the centers that have to be created are those located in the quadrants 9 (capacity of 2,000), 19 (capacity of 2,000), 34 (capacity of 2,000), 40 (capacity of 2,000), 53 (capacity of 2,000), 61 (capacity of 1,000), 69 (capacity of 2,000), 71 (capacity of 1,800), 86 (capacity of 1,600) and 91 (capacity of 1,800). From this mathematical solution, it is observed that, for the district of Rímac, centers 9, 19 and 34 will cover the demand; for Lima, there will be centers 34, 40, 53, 61 and 69; for Breña, there will be only center 53; for La Victoria, there will be centers 61, 69, 71, 86 and 91; finally, for San Luis, there will be centers 61,86 and 91 .

Through this algorithm, it is possible to assign one center to more than one district. Following that criteria, the center 34 will be assigned to 2 districts (Rímac and Lima); center 53 to 2 districts (Lima and Breña), center 61 to 3 districts (Lima, La Victoria and San Luis), center 69 to 2 districts (Lima and La Victoria), center 86 to 2 districts (La Victoria and San Luis) and center 91 to 2 districts (La Victoria and San Luis). This method allows optimizing the total number of centers required to cover the demand of different districts. 


\section{CONCLUSIONS AND RECOMMENDATIONS}

The level of learning of basic subjects such as mathematics is increasing over the years in Peru. Nevertheless, with the segmentation of districts by socioeconomic factors and grouping them in district areas, remarkable differences in scores between the areas that have better conditions (Lima Moderna) and the other areas (Lima Norte, Lima Este, Lima Centro and Lima Sur) are observed. This supports the idea that household incomes are an important variable in the education of students in Peru. For that reason, establishing tutoring centers in places that have registered low scores in the ECE assessment and also have low economic resources will have a great impact on the level of achievement of the expected learning for the current grade, because these centers will provide the opportunity to access to a complementary education.

It is observed that only ten centers are required to cover all the demands of the five evaluated districts, which are divided into a total of thirty-seven zones. In fact, based on these results, it is noted that five of the ten centers would be assigned to two districts each, and one center would be assigned to three districts. The proposed algorithm allows the project to use only the minimum necessary number of centers to provide tutoring to students and, through this, improve the quality of learning and the level of achievement expected for the evaluated grade.

For the scope of this paper, only the results of a specific grade level, a specific subject and some districts of the Lima Metropolitan Area have been studied. It is important to extend this analysis to more critical areas of Lima, such as Lima Norte and Lima Sur, which have worse economic conditions, and extend to rural areas in different departments of Peru. In addition, it is important to add some variables to improve the results obtained through the proposed algorithm, considering aspects such as the availability of land and the cost per square meter, which varies according to the district. Moreover, the delimitation of the quadrants can be adjusted according to the level of accuracy with which it is desired to obtain the reference point for the implementation of a tutoring center.

\section{REFERENCES}

[1] Ministerio de Educación del Perú. (2018). Resultados 2018 - Evaluaciones de logros de aprendizaje.

http://umc.minedu.gob.pe/wp-content/uploads/2019/04/presentacion-webECE2018-1.pdf

[2] Bray, M. (2007). The shadow education system: private tutoring and its implications for planners. Fundamentals of Educational Planning 61, Paris: UNESCO International Institute for Educational Planning (IIEP). https://unesdoc.unesco.org/ark:/48223/pf0000118486

[3] O'Connell, M. (2019). Is the impact of SES on educational performance overestimated? Evidence from the PISA survey. Intelligence, Elsevier, volume $75(\mathrm{C})$, pages 41-47.

https://www.sciencedirect.com/science/article/abs/pii/S016028961830239 3

[4] Breton, T. \& Canavire-Bacarreza, G. (2017). Low test scores in Latin America: poor schools, poor families or something else? Compare: A Journal of Comparative and International Education, volume 48, issue 5 , pages $733-748$ https://www.tandfonline.com/doi/abs/10.1080/03057925.2017.1342530

[5] Ireson, J. (2004). Private Tutoring: how prevalent and effective is it? London Review of Education, volume 2, number 2, pages 109-122 https://www.researchgate.net/publication/44836264_Private_tutoring_Ho w_prevalent_and_effective_is_it

[6] Ministerio de Educación del Perú. (2018). ¿Qué aprendizajes logran nuestros estudiantes? - Evaluaciones de logros de aprendizaje 2018. http://umc.minedu.gob.pe/wp-content/uploads/2018/10/Informe-NacionalECE-2018.pdf

[7] Ministerio de Educación del Perú (2018). Reporte técnico de las Evaluaciones Censales y Muestrales de Estudiantes 2018. http://umc.minedu.gob.pe/wp-content/uploads/2019/08/RT-Evaluaciones2018.pdf

[8] Instituto Nacional de Estadística e Informática (2018). Resultados definitivos de los censos nacional 2017 - Provincia de Lima, tomo I. https://www.inei.gob.pe/media/MenuRecursivo/publicaciones_digitales/E st/Lib1583/ 